\title{
Immune-Checkpoint Inhibitors in Platinum-Resistant Ovarian Cancer
}

\author{
Alice Indini ${ }^{1}(\mathbb{D})$, Olga Nigro ${ }^{2}$, Csongor György Lengyel ${ }^{3}$, Michele Ghidini ${ }^{4}\left(\mathbb{D}\right.$, Angelica Petrillo ${ }^{5}$ (D), \\ Salvatore Lopez ${ }^{6}$, Francesco Raspagliesi ${ }^{6}$, Dario Trapani ${ }^{7}$, Shelize Khakoo ${ }^{8, *}$ (D) and Giorgio Bogani ${ }^{6, *(D)}$
}

\section{check for}

updates

Citation: Indini, A.; Nigro, O.; Lengyel, C.G.; Ghidini, M.; Petrillo,

A.; Lopez, S.; Raspagliesi, F.; Trapani,

D.; Khakoo, S.; Bogani, G. Immune-

Checkpoint Inhibitors in Platinum-

Resistant Ovarian Cancer. Cancers

2021, 13, 1663. https://doi.org/

10.3390/cancers 13071663

Academic Editors: Antonio Curti,

Alessandro Isidori, Giuseppe Lo

Russo and Marina Chiara Garassino

Received: 8 March 2021

Accepted: 30 March 2021

Published: 1 April 2021

Publisher's Note: MDPI stays neutral with regard to jurisdictional claims in published maps and institutional affiliations.

Copyright: (c) 2021 by the authors. Licensee MDPI, Basel, Switzerland. This article is an open access article distributed under the terms and conditions of the Creative Commons Attribution (CC BY) license (https:/ / creativecommons.org/licenses/by/ $4.0 /)$.
1 Medical Oncology Unit, Fondazione IRCCS Ca' Granda Ospedale Maggiore Policlinico, Via Francesco Sforza 35, 20122 Milan, Italy; alice.indini@policlinico.mi.it

2 Medical Oncology, ASST Sette Laghi, Ospedale di Circolo e Fondazione Macchi, 21100 Varese, Italy; olga.nigro@istitutotumori.mi.it

3 Head and Neck Surgery, National Institute of Oncology Hungary, Ráth György u. 7-9, 1122 Budapest, Hungary; lengyel.csongor@gmail.com

4 Medical Oncology Unit, Fondazione IRCCS Ca' Granda Ospedale Maggiore Policlinico, Via Della Commenda 19, 20122 Milan, Italy; Michele.ghidini@policlinico.mi.it

5 Medical Oncology Unit, Ospedale del Mare, Via E. Russo, and University of Study of Campania "L.Vanvitelli", Via Pansini n.5, 80100 Naples, Italy; angelic.petrillo@gmail.com

6 Fondazione IRCCS Istituto Nazionale dei Tumori di Milano, Via Giacomo Venezian 1, 20133 Milano, Italy; salvatore.lopez@istitutotumori.mi.it (S.L.); raspagliesi@istitutotumori.mi.it (F.R.)

7 European Institute of Oncology, IRCCS, New Drug Development for Innovative Therapies, Via Ripamonti 435, 20141 Milan, Italy; Dario.trapani@ieo.it

8 Gynecologic Oncology Unit, Department of Medicine, The Royal Marsden NHS Foundation Trust, Downs Road, Sutton SM2 5PT, UK

* Correspondence: Shelize.Khakoo@rmh.nhs.uk (S.K.); giorgio.bogani@istitutotumori.mi.it (G.B.); Tel.: +39-022-390-2507 (G.B.); Fax: +39-025-503-2659 (G.B.)

Simple Summary: Patients with platinum-resistant ovarian cancer experience poor prognosis. No mature evidence supports the routine adoption of immunotherapy alone in this setting. However, the combination of immunotherapy with target therapies seems to be a promising option in patients with ovarian cancer. Ongoing trials are testing the combination between immune therapy and other target therapies, including PARP inhibitors, TKI, and anti-angiogenetic therapies. Further evidence is needed to assess the real impact and cost-effectiveness of immmunotherapic agents in platinum-resistant ovarian cancer.

Abstract: Platinum-resistant ovarian cancer (OC) has limited treatment options and is associated with a poor prognosis. There appears to be an overlap between molecular mechanisms responsible for platinum resistance and immunogenicity in OC. Immunotherapy with single agent checkpoint inhibitors has been evaluated in a few clinical trials with disappointing results. This has prompted exploration of immunotherapy combination strategies with chemotherapy, anti-angiogenics, poly (ADP-ribose) polymerase (PARP) inhibitors and other targeted agents. The role of immunotherapy in the treatment of platinum-resistant OC remains undefined. The aim of this review is to describe the immunobiology of OC and likely benefit from immunotherapy, discuss clinical trial data and biomarkers that warrant further exploration, as well as provide an overview of future drug development strategies.

Keywords: platinum-resistance; ovarian cancer; immunotherapy; immune checkpoint inhibitors; new drugs

\section{Introduction}

Ovarian cancer (OC) is the eighth most common cancer in women. Worldwide the OC incidence and mortality figures rank just below those for cancers of the cervix and uterus, accounting for 295,414 new cases and 184,799 deaths in 2018 [1,2]. In the United States 
(US), 21,750 new cases and 13,940 OC-related deaths are projected to occur in 2020. OC is amongst the leading causes of cancer-related death in women, particularly in the 40-79 year age group. Survival rates vary significantly depending on the disease stage at diagnosis. Ninety percent of patients with early-stage disease are alive at 10 years compared with only around $15 \%$ with advanced disease, despite optimal treatment [3]. Over 50\% of patients present with advanced disease due to a lack of effective screening measures and the absence of specific symptoms which leads to diagnostic delay [4]. Most OC arises from the epithelial tissue $(90 \%)$, and most of them seems originating from the fallopian tube [5]. The following histologic subtypes of epithelial OC are recognized according to the World Health Organization (WHO) classification: serous $(70 \%)$, endometrioid $(10 \%)$, clear cell $(10 \%)$, and other types including mucinous tumors $(10 \%)$. This classification was updated in 2014, with a distinction being made between two variants of serous carcinoma (i.e., high-grade serous carcinoma (HGSC), and low grade), characterized by distinct oncogenic pathways, differences in therapeutic approach, and prognosis. According to the latest WHO classification, high-grade cancers are all included in the HGSC group, due to similar biologic characteristics and prognosis [5]. HGSC is characterized by genomic instability and p53 mutations, while low-grade tumors tend to be more indolent and show dysregulation in the mitogen-activated-kinases (MAPK), with mutations predominantly observed in KRAS and BRAF and a few in other RAS proteins and MEK [5].

Although the therapeutic landscape and hence survival outcomes have improved for OC over the years with the inclusion of agents such as poly (ADP-ribose) polymerase 1 (PARP) inhibitors and the anti-angiogenic bevacizumab, surgery and platinum-based chemotherapy remains the mainstay of treatment. While initial response rates to chemotherapy can be high, most patients relapse and have or eventually develop resistance to platinum-based chemotherapy which confers a poor prognosis with a median overall survival (OS) of $<12$ months. There is therefore a clear unmet need to improve outcomes in this subset of patients.

Immune-checkpoint inhibitors (ICI) have revolutionized the treatment paradigm of several tumors such as melanoma and cutaneous squamous cell carcinoma, non-small cell lung cancer (NSCLC), urinary tract carcinomas, and head and neck cancers, and their use in other tumor types remains under investigation. The most widely adopted immunotherapy strategies in clinical practice include targeting the cytotoxic T-lymphocyte antigen 4 (CTLA4 ), and the programmed cell death protein 1 (PD-1) and its ligand (PD-L1). However, not all tumors display the same degree of sensitivity to immunotherapy [6]. In OC patients, immunotherapy might be a promising option as adjuvant therapy (as in the VITAL trial) and for the treatment of recurrent/progressive disease [7]. This review aims to analyze the current landscape of immunotherapy in OC, focusing mainly on the setting of platinumresistant OC. We provide an overview of the immunogenicity of $\mathrm{OC}$ and explore potential strategies to overcome immune-resistance in this disease.

\section{Platinum-Resistant OC Models}

\subsection{Definitions of Platinum-Sensitivity, and Resistance}

The platinum-free interval (PFI) is associated with prognosis and has been defined by the Gynecologic Cancer InterGroup (GCIG) consensus statement as the time from the last dose of platinum until documented disease progression. In patients with recurrent $O C$, the disease is defined as refractory, platinum-resistant, partially platinum-sensitive, or platinum-sensitive by a PFI of $\leq 4$ weeks, $<6$ months, 6-12 months, or $>12$ months respectively [8]. This classification has been conventionally accepted also by the ESMOESGO consensus [9] and is used in most clinical trials as well as in clinical decision-making for treatments $[10,11]$. It should be mentioned that the definition of "platinum partially sensitive" OC has not been fully validated and utilized variably and inconsistently across clinical trials. Notably, the resistant phenotype can arise at different stages of the natural history of OC. Tumor cells may present with de novo or intrinsic resistance to platinum 
drugs referred to as primary platinum-resistance (PPR) or become resistant during therapy, known as acquired platinum-resistance (APR) [7-17].

\subsection{Molecular Mechanisms of Platinum Resistance: A Continuum of Platinum-Resistance and Immunogenic Phenotypes?}

Mechanisms of platinum-resistance are multi-factorial and include genetic and epigenetic alterations, apoptotic escape, and environmental factors [17]. Interestingly, associations between molecular mechanisms responsible for platinum resistance and immunogenicity in OC have been suggested, though mostly derived from speculative retrospective analyses and exploratory statistical exercises. Accordingly, a possible overlap of selected mechanisms conferring platinum-resistance, and immunogenicity might be just inexistent, resulted from misinterpretations of uncontrolled datasets, and should not be used to justify any bio-plausibility in this regard that platinum-resistant $\mathrm{OC}$ is tout court immuneresponsive.

Cognizant of all the speculative nature of the assumptions, some mechanisms associated with platinum-resistance have been reported to confer some features of immuneresponse $[17,18]$. In this regard, key mechanisms possibly associated with sensitivity to immune-agents have been correlated to a platinum-resistant phenotype of OC. The loss of the tumor-suppressor gene AT-rich interaction domain A (ARID1A), a multidrug resistance-associated protein 2 (MRP2) regulator, has been shown to lead to a platinumresistant phenotype in a preclinical tumor model [19-21]. The loss of function of ARID1A has also been associated with molecular alterations in DNA repair mechanisms and increasing mutation frequency, similar to those observed with the loss of mismatch repair (MMR). ARID1A-deficient ovarian cells present with a microsatellite instability (MSI) genomic signature with an increased mutational burden, along with elevated numbers of tumorinfiltrating lymphocytes, and PD-L1 expression, thereby providing a rationale to explore the role of immunotherapy in this setting. Indeed, in a murine model of OC, ARID1Adeficient tumors showed a higher response rate and improved survival when exposed to anti-PD1 ICIs [20]. The loss of MMR proteins (i.e., MMR deficiency), which are responsible for correcting single-strand DNA errors, leads to MSI, either by genetic inheritance or somatically acquired. MLH1 acquired deficiency related to gene promoter methylation, or MLH2 mutation, are the most frequent causes of MSI in OC [21-29]. Besides, the survival mechanism to overcome replication arrest due to DNA damage is performed by several DNA polymerases, including POLH. An elevated baseline expression of POLH in OC stem cells has been linked to intrinsic chemo-resistance [30-33]. Interestingly, both MMR deficiency and alterations in POL-proteins have been associated with platinum-resistance and an immune-responsive phenotype, therefore representing speculatively potential biomarkers for immunotherapy response in a subgroup of OC.

Germline and somatic mutations in the BRCA1 and 2 genes have been identified in $17 \%$ and $6 \%$ of patients with HGSC respectively, and are associated with improved response to both platinum compounds and other DNA targeting agents such as PARP inhibitors [34]. The presence of BRCA mutations has also been associated with a mutagenic phenotype with increased neoantigens [35-40]. One study used The Cancer Genome Atlas dataset and reported a potential role of BRCA alterations to predict immunogenicity in HGSC, with higher immunotherapy-responsive signatures in patients harboring the BRCA1-mutation; however, only newly diagnosed tumors were considered [34].

A discussion of all concurrent mechanisms contributing to platinum-resistance in $\mathrm{OC}$ has been extensively reviewed elsewhere and is beyond the scope of this review [17]. However, an improved understanding of the molecular mechanisms underlying resistance has propelled the development of therapeutic targets both in this setting and as a means to delay the onset of chemoresistance [38]. More recently, the recognition that platinumresistant OC has some features indicative of an immune responsive phenotype has led to an interest in evaluating immunotherapy in this context [39,40]. However, all the evidence reported is speculative, and the immune-context of platinum-resistant OC seems to be heterogeneous, and not immediately resulting in an immunogenic phenotype. The reductio 
ad unum of the platinum-resistant phenotype to an immunogenic cancer type is currently inappropriate, unbiased, and largely speculative. However, a subgroup of treatmentresistant OC, reliably a tiny subgroup, may present molecular stigmata associated with immune-response.

\section{The Current Management of Platinum-Resistant OC: Few Signs of Progress in Therapies, Few Options for Clinical Care}

The current treatment paradigm for platinum-resistant OC involves the sequential use of single-agent chemotherapy and avoids compounds with cross-resistance to platinum. Single-agent chemotherapy provides similar responses to combination treatment with less toxicity. Paclitaxel, gemcitabine, topotecan, and liposomal anthracyclines have shown response rates ranging from $10 \%$ to $15 \%$, with progression-free survival (PFS) of $\sim 3$ months [41,42]. The attempts to implement targeted agents in this setting provided small or no added benefits in the treatment, including the antiangiogenic drugs bevacizumab and cediranib [43-47].

Continuous low-dose chemotherapy administration (i.e., metronomic schedules) has also been investigated in platinum-resistant OC, based on possible anti-angiogenic and speculated immune-modulating activities $[47,48]$. Findings across studies have consistently shown that the therapeutic armamentarium for platinum-resistant $\mathrm{OC}$ is associated with only modest benefit. There is therefore a clear need to improve outcomes in this subset of patients and this should be considered a research priority.

\section{The Immune Contexture and Immunogenicity in $\mathrm{OC}$}

$\mathrm{OC}$ is characterized by a high copy number variation (CNV). These alterations included deletion of genes implicated in homologous recombination (BRCA), base excision repair, and DNA damage signaling. The role of immunotherapy in OC is still controversial. In particular, platinum-resistant OC should not be considered an "immunogenic disease", but some subtypes may present features associated with better benefits from immunotherapy agents. In some patients with platinum-resistant disease, markers of an antitumor immune response can be detected in peripheral blood, tumor tissue, and ascites fluid $[49,50]$. Like in several different solid tumors, the presence of tumor-infiltrating lymphocytes (TILs) in the tumor microenvironment (TME) of OC is associated with improved survival, as showed in studies on tumor samples from patients with OC [51]. Conversely, the lack of TILs is associated with worse survival. However, distinct immune cell subtypes can be identified within the TILs, playing different roles. Intra-tumoral CD3 +TILs were associated with improved survival in advanced stage OC in a report by Zhang et al. [52]. A study by Sato et al. [53] showed that intraepithelial CD8+, rather than CD3+ TILs, were associated with a favorable prognosis. A meta-analysis including 1815 OC patients confirmed the prognostic value of intraepithelial CD8+ TILs, regardless of tumor grade, stage, or histological subtype although it should be noted that heterogeneity between studies was significant [54]. The presence of infiltrating B lymphocytes has been associated with improved prognosis [55]. Moreover, evidence suggests that the presence of both B cells and CD8+ TILs is associated with increased survival in OC patients, compared to CD8+ TILs alone [56].

However, in the tumor microenvironment (TME), multiple factors counteract the activity of TILs, thereby facilitating cancer progression through immune escape mechanisms. Regulatory $\mathrm{T}$ lymphocytes (Tregs) play a fundamental role in mechanisms of immune escape and evasion $[57,58]$. Tumor-associated macrophages (TAMs), one of the major subpopulations of myeloid cells in OC ascites, promote an immune-suppressive milieu through reduced IL-12 production, as shown in a preclinical in-vitro and ex vivo model [59-61]. TAMs promote mechanisms of immune suppression, favoring cancer growth, angiogenesis, and metastasis. Other subtypes of immune-suppressive cells include the natural killer (NK), and the myeloid-derived suppressor cells (MDSCs) which inhibit both adaptive and innate immunity through several complex mechanisms. Like TAMs and Tregs, MDSC negatively impacts patient survival by enhancing cancer progression and metastasis [62]. 
Together with immune-suppressive cells, several inhibitory molecules can dampen the CTL-mediated antitumor response within the OC TME. These immune pathways involve the programmed cell death-ligand 1 (PD-L1), the cytotoxic T lymphocyte antigen 4 (CTLA-4), the lymphocyte activation gene 3 (LAG-3) protein, and the T cell immunoglobulin and mucin domain-containing protein 3 (TIM-3) [63-65]. In platinum-resistant OC, TILs often express PD-1, while malignant cells can show high levels of PD-L1 [66,67]. A study comparing the prognosis of patients with OC according to PD-L1 expression showed that patients with high PD-L1 have significantly worse prognoses when compared with those showing lower PD-L1 expression [68]. An inverse correlation was observed between PD-L1 expression and the CD8+ TILs count, suggesting that PD-L1 expression on tumor cells can directly suppress antitumor CD8+ T cells. In multivariate analysis, the expression of PD-L1 on tumor cells and intraepithelial CD8+ T-lymphocyte counts were independent prognostic factors. However, there is a lack of concordance on this topic among different studies [69,70], mostly due to different staining methods, type of cells used, score for surface PD-L1 expression (tumor cell vs. immune infiltrate vs. both), and the optimal cut-off to define PD-L1 positivity.

OC cells can evade the host immune system through several other mechanisms, including loss of MHC expression [71] and up-regulation of immunosuppressive factors, such as TGF- $\beta$ [72] indoleamine 2,3-dioxygenase (IDO) [73], and cyclooxygenases (COX-1 and COX-2) [74].

Although evidence suggests there might be a rationale for immunotherapy in platinumresistant OC, the complex interaction between OC cells and cells of the immune system may partly explain the limited benefit observed with immune-agents in this disease, as well as the non-reproducibility of some findings. In general, platinum-resistant OC seems not a primary immune-responsive cancer type, although some of these tumors can present immunogenic features possibly deriving a benefit from pharmacological manipulations of the immune response or conferring better prognosis.

For example, many of the key original works showing some prognostic meaning of TILs were based on tissue samples obtained before any chemotherapy, therefore not capturing, or adjusting for key prognostic covariates. Moreover, these findings are largely unconfirmed in the clinical setting and derive from in vitro and animal models, and some retrospective patient series This is a major limitation and may explain the divergencies in the literature on this topic, with different conclusions. Therefore, data suggesting a prognostic role of immune-related biomarkers in platinum-resistant OC are to be considered generally inconclusive, essentially unconfirmed.

\section{Immunotherapy for Platinum-Resistant or Refractory OC}

\subsection{Trials Investigating Single-Agent Immune-Checkpoint Inhibitors}

To date, only a few clinical trials have investigated immune checkpoint inhibitors (ICI) as a treatment for advanced recurrent OC [75]. Table 1 displays the characteristics and results of the principal clinical trials of immunotherapy in OC.

A phase II study of the anti-CTLA4 antibody ipilimumab in patients with platinumsensitive recurrent OC $(n=40)$, reported an ORR of $10.3 \%$, with a high incidence of treatment-related adverse events (AEs) (i.e., $50 \%$ of patients with grade $3 \mathrm{AEs}$ ) [76]. The high rate of toxicity might be related to the dose of ipilimumab administered per protocol, which is much higher than the approved schedule of ipilimumab for other tumors (e.g., melanoma). After this initial experience with ipilimumab, there have been few trials investigating anti-CTLA4 in recurrent OC. Most trials have focused on anti-PD1/PDL1 therapy. 
Table 1. Key clinical trials of immunotherapy for recurrent ovarian carcinoma.

\begin{tabular}{|c|c|c|c|c|c|c|c|c|}
\hline $\begin{array}{l}\text { Trial Name, } \\
\text { Identification } \\
\text { Number }\end{array}$ & Study Design & Drug(s) & $\begin{array}{l}\text { Disease } \\
\text { Setting }\end{array}$ & $\begin{array}{c}\text { Sample } \\
\text { Size }\end{array}$ & ORR & $\begin{array}{l}\text { mPFS, mo } \\
(95 \% \text { CI })\end{array}$ & $\begin{array}{c}\operatorname{mOS}, \text { mo } \\
(95 \% \text { CI })\end{array}$ & $\underset{\text { Incidence }}{\text { TRAEs G } \geq 3}$ \\
\hline NCT01611558 & Phase II & $\begin{array}{c}\text { Ipilimumab } 10 \\
\text { mg/kg q3w per } 4 \\
\text { cycles; maintenance } \\
\text { q12w }\end{array}$ & $\begin{array}{l}\text { Platinum- } \\
\text { sensitive }\end{array}$ & $n=40$ & $10.3 \%$ & - & - & $50 \%$ \\
\hline NCT00729664 & Phase I & $\begin{array}{c}\text { BMS-936559 } 3 \\
\mathrm{mg} / \mathrm{kg}-10 \mathrm{mg} / \mathrm{kg} \\
\mathrm{q} 2 \mathrm{w}\end{array}$ & $\begin{array}{l}\text { Recurrent } \\
\text { disease }\end{array}$ & $n=17$ & $6 \%$ & - & - & $\mathrm{ND}^{*}$ \\
\hline UMIN000005714 & Phase II & $\begin{array}{c}\text { Nivolumab } 1 \\
\mathrm{mg} / \mathrm{kg}-3 \mathrm{mg} / \mathrm{kg} \text { q2w }\end{array}$ & $\begin{array}{l}\text { Platinum- } \\
\text { resistant }\end{array}$ & $n=20$ & $15 \%$ & $3.5(1.7-3.9)$ & $20.0(7.0-\mathrm{NR})$ & $40 \%$ \\
\hline $\begin{array}{c}\text { KEYNOTE- } \\
\text { 028, } \\
\text { NCT02054806 }\end{array}$ & Phase Ib & $\begin{array}{l}\text { Pembrolizumab } 10 \\
\mathrm{mg} / \mathrm{kg} \mathrm{q} 3 \mathrm{w}\end{array}$ & $\begin{array}{l}\text { PD-L1 + } \\
\text { recurrent } \\
\text { disease }\end{array}$ & $n=26$ & $11.5 \%$ & $1.9(1.8-3.5)$ & $13.8(6.7-18.8)$ & $3.8 \%$ \\
\hline $\begin{array}{c}\text { KEYNOTE- } \\
100, \\
\text { NCT02674061 }\end{array}$ & Phase II & $\begin{array}{l}\text { Pembrolizumab } 200 \\
\text { mg q3w }\end{array}$ & $\begin{array}{c}\text { Recurrent } \\
\text { disease } \\
\text { (cohort A: PFI } \\
3-12 \mathrm{mo} \\
\text { cohort B: PFI } \\
\geq 3 \mathrm{mo} \text { ) }\end{array}$ & $n=376$ & $8 \%$ & $\begin{array}{l}\text { A: } 2.1(2.1-2.2) \\
\text { B: } 2.1(2.1-2.6)\end{array}$ & $\begin{array}{c}\text { A: NR } \\
(16.8-\mathrm{NR}) \\
\text { B: } 17.6 \\
(13.3-\mathrm{NR})\end{array}$ & $19.7 \%$ \\
\hline $\begin{array}{c}\text { JAVELIN, } \\
\text { NCT01772004 }\end{array}$ & Phase $\mathrm{Ib}$ & $\begin{array}{c}\text { Avelumab } 10 \mathrm{mg} / \mathrm{kg} \\
\mathrm{q} 3 \mathrm{w}\end{array}$ & $\begin{array}{l}\text { Recurrent } \\
\text { disease }\end{array}$ & $\mathrm{n}=125$ & $9.6 \%$ & $10.2(5.4-16.7) * *$ & $11.2(8.7-15.4)$ & $7.2 \%$ \\
\hline $\begin{array}{c}\text { TOPACIO, } \\
\text { NCT02657889 }\end{array}$ & Phase I/II & $\begin{array}{c}\text { Niraparib } 200 \text { mg QD } \\
+ \text { Pembrolizumab } 200 \\
\text { mg q3w }\end{array}$ & $\begin{array}{l}\text { Recurrent } \\
\text { disease }\end{array}$ & $n=62$ & $18 \%$ & $3.4(2.1-5.1)$ & - & $6 \%$ \\
\hline $\begin{array}{l}\text { MEDIOLA, } \\
\text { NCT02734004 }\end{array}$ & Phase I/II & $\begin{array}{l}\text { Olaparib } 400 \text { mg BID } \\
\text { + Durvalumab } 1500 \\
\text { mg q3w }\end{array}$ & $\begin{array}{l}\text { Platinum- } \\
\text { sensitive } \\
\text { gBRCAm }\end{array}$ & $n=34$ & $72 \%$ & - & - & - \\
\hline NCT02485990 & Phase I/II & $\begin{array}{c}\text { Tremelimumab } \\
\text { 10mg/kg q4wx7 then } \\
\text { q12w alone or } \\
\text { +Olaparib 150mg BID } \\
\text { or } \\
\text { Tremelimumab } 3 \\
\text { mg/kg q4wx7 then } \\
\text { q12w + Olaparib } 150 \\
\text { mg BID }\end{array}$ & $\begin{array}{l}\text { Recurrent } \\
\text { disease }\end{array}$ & $N=24$ & $8 \%^{\dagger}$ & $17 \%$ PFS > $6 \mathrm{mo}$ & - & $42 \%$ \\
\hline NCT02873962 & Phase II & $\begin{array}{c}\text { Bevacizumab } 10 \\
\text { mg/Kg }+ \\
\text { Nivolumab } 240 \mathrm{mg} \\
\text { q2w }\end{array}$ & $\begin{array}{l}\text { Recurrent } \\
\text { disease }\end{array}$ & $N=38$ & $28.9 \%$ & 9.4 (6.7-NA) & - & $23.7 \%$ \\
\hline NCT02498600 & Phase II & $\begin{array}{c}\text { Nivolumab } 3 \mathrm{mg} / \mathrm{kg} \\
\text { q2wx4 or Nivolumab } \\
3 \mathrm{mg} / \mathrm{Kg}+ \\
\text { Ipilimumab } 1 \mathrm{mg} / \mathrm{Kg} \\
\text { q3wx4, maintenance } \\
\text { nivolumab } 3 \mathrm{mg} / \mathrm{kg} \\
\text { q2wx42 max }\end{array}$ & $\begin{array}{l}\text { Recurrent } \\
\text { disease }\end{array}$ & $N=100$ & $\begin{array}{c}\text { Nivo: } \\
12.2 \% \\
\text { Ipi/Niv:31.4\% }\end{array}$ & $\begin{array}{c}\text { Nivo:2 } \\
\text { Ipi/Nivo:3.9 (HR } \\
0.53 ; 0.34-0.82)\end{array}$ & $\begin{array}{c}\text { Nivo:21.8 } \\
\text { Ipi/Nivo:28.1 } \\
\text { (HR 0.79; } \\
0.44-1.42 \text { ) }\end{array}$ & $\begin{array}{c}\text { Nivo:33\% } \\
\text { Ipi/Nivo: } 49 \%\end{array}$ \\
\hline
\end{tabular}

(source: www.clinicaltrials.gov, accessed on 1 February 2020). ${ }^{*}$ incidence of adverse events was assessed in the whole trial population and not specifically in the ovarian cancer subpopulation of patients (for whole data on safety, refer to Brahmer, J.R.; Tykodi, S.S.; Chow, L.Q.; et al. Safety and activity of anti-PD-L1 antibody in patients with advanced cancer. N. Eng. J. Med. 2012; 36618: 2455-2465, ** 1-year progression free survival, ${ }^{\dagger}$ ORR amongst patients receiving combination treatment, BID, bis in die; gBRCAm, germline breast related cancer antigen mutant; mo, months; mOS, median overall survival; mPFS, median progression free survival; ND, not determined; NR, not reached; ORR, overall response rate; PFI, platinum-free interval; QD, once daily; q2-3-12w, every 2-3-12 weeks; TRAEs, treatment-related adverse events.

Brahmer et al. reported the results of the phase I trial of the anti-PD-L1 antibody BMS-936559 (MDX-1105) in solid tumors (regardless of PD-L1 expression) and included 17 patients with recurrent OC [77]. The disease control rate (DCR) in this small cohort was $23 \%$, and the median duration of response (DOR) was 1.3 months. The first phase II trial exploring two different schedules of nivolumab $(1 \mathrm{mg} / \mathrm{kg}$ or $3 \mathrm{mg} / \mathrm{kg}$ every 2 weeks) in 20 patients with platinum-resistant OC showed more promising results. The ORR was $15 \%$, with a DCR of $45 \%$ [77]. The median PFS was 3.5 months (95\% CI, 1.7 to 3.9 months), and the median OS was 20 months (95\% CI, 7 months to not reached). Eighty percent of patients had high PD-L1 expression in their tumor tissue, however, PD-L1 expression was not found to be associated with ORR [78]. In the KEYNOTE-028 phase I trial which included PD-L1 positive OC $(n=26)$, treatment with single-agent pembrolizumab resulted in an ORR of $11.5 \% ; 7$ patients (26.9\%) achieved SD as the best response [78]. Median PFS and OS were 1.9 (95\% CI, 1.8-3.5) and 13.8 (95\% CI, 6.7-18.8) months, respectively [78]. The subsequent phase 2 KEYNOTE-100 trial explored single-agent pembrolizumab in two 
different cohorts of recurrent OC patients: cohort A enrolled 285 patients who had received $\leq 3$ prior lines of treatment, with a treatment-free interval (TFI) of 3-12 months; cohort B enrolled 91 patients, who had received $4-6$ prior lines with a TFI of $\geq 3$ months [79]. ORR was $7.4 \%$ for cohort $A$ and $9.9 \%$ for cohort $B$, with a median DOR of 8.2 months for cohort $\mathrm{A}$ and not reached for cohort B; DCR was $37.2 \%$ and $37.4 \%$, in cohort A and B, respectively. Response rates differed according to PD-L1 expression, using the combined positive score (CPS), with an ORR of $4.1 \%$ for CPS $<1,5.7 \%$ CPS $\geq 1$, and $10.0 \%$ for CPS $\geq 10$. PFS was 2.1 months for both cohorts (95\% CI 2.1-2.2 for cohort A and 95\% CI 2.1-2.6 for cohort B); the median OS was not reached for cohort A (95\% CI 16.8-not reached) and was 17.6 months for cohort B (95\% CI 13.3-not reached). The protocol-specified final analysis of this trial has recently been presented at the American Society of Clinical Oncology (ASCO) annual meeting, confirming a trend toward better ORR and longer OS in both study cohorts with higher PD-L1 expression [80].

Recently, the JAVELIN trial evaluated another anti-PD-L1 antibody (avelumab) in recurrent OC. The JAVELIN trial was a phase $1 \mathrm{~b}$ trial enrolling patients with several solid tumors, with an expansion cohort that assessed efficacy outcomes in patients with recurrent OC unselected for PD-L1 expression $(n=124)$ [81]. Preliminary results from this trial showed an ORR of $9.7 \%$, and a DCR of $54 \%$ in patients with OC. Patients with PD-L1 positive tumors ( $\geq 1 \%$ tumor cell staining), accounting for $77 \%$ of all patients, had better ORR compared with patients with PD-L1 negative tumors (12.3\% vs. 5.9\%, respectively). Overall, median PFS was 11.3 weeks (95\% CI: 6.1-12.0) and median OS was 10.8 months (95\% CI: 7-16.1). Data regarding safety of single-agent anti-PD1/PD-L1 in recurrent OC mirror those of melanoma and NSCLC trials, confirming the overall good tolerability of treatment and the low rate of severe (i.e., grade 3 according to CTCAE v 4.0) treatmentrelated adverse events AEs ( 10-15\%) [81-92]. The most common immune-related AEs (irAEs) of any grade occurring in $10 \%$ of patients across trials were: fatigue (which is also the most common overall toxicity), diarrhea, nausea, increased lipase, skin reactions, and thyroid dysfunction. Overall, the observed rate of treatment discontinuation due to treatment-related AEs was low [81-92].

Despite a clear rationale for investigating immunotherapy in $\mathrm{OC}$, results from the aforementioned clinical trials of single-agent ICIs in recurrent and/or resistant OC have been disappointing. Efforts to improve treatment efficacy have focused on combining immunotherapy with cytotoxic chemotherapy or targeted agents including anti-angiogenic or combining different ICIs.

\subsection{Trials Investigating Combination Treatment with ICIs and a Discussion of the Rationale}

One of the most promising combination strategies is co-targeting PARP and PD-1 [82]. There is a strong rationale in support of this strategy, given that homologous recombination deficient (HRD) tumors show high expression of PD-1, and the preclinical evidence that double-strand DNA break inducing drugs such as PARP inhibitors allow the accumulation of mutations and hence neoantigens, stimulate upregulation of PD-L1 in tumor cells and activate the innate immune system via the STING pathway with type-I interferon production resulting in optimal recruitment of dendritic cells and priming of T effector cells [83].

Results from two combination trials of PARP inhibitors and anti-PD1/PD-L1 antibodies have recently been presented [84,85]. The TOPACIO/KEYNOTE-162 [85] was a single-arm phase $1 / 2$ study of niraparib in combination with pembrolizumab, in women with advanced/metastatic triple-negative breast cancer (TNBC) or recurrent OC, irrespective of BRCA mutation status. Analysis of the pooled OC cohort ( $n=62$ patients) showed an ORR of $18 \%$ (90\% CI, 11-29\%), with a DCR of $65 \%$ (90\% CI, 54-75\%). Subgroup analysis revealed that ORRs were consistent regardless of platinum-sensitivity, previous bevacizumab treatment, or tumor BRCA or HRD biomarker status. The MEDIOLA trial [84] evaluated the combination of olaparib and durvalumab in patients with platinum-sensitive ROC with known BRCA mutation $(n=34)$. Preliminary results of this trial showed an ORR of $72 \%$, and a 12 -week DCR of $81 \%$. Response rates were higher in patients who had received only 
one prior line of chemotherapy and were not associated with PD-L1 expression. The safety of combination treatment was assessed in both trials: the most common treatment-related AEs of any grade were fatigue, nausea, anemia, and constipation. The incidence of irAEs in the TOPACIO trial was 19\%, with grade 3 irAEs occurring in $6 \%$ and no reports of treatment-related deaths. More recently, the results of combination treatment with the antiCTLA4 antibody tremelimumab and the PARP inhibitor olaparib were presented at ASCO 2020 [86] Fifty percent of patients receiving combination treatment were platinum-resistant and $75 \%$ had no BRCA mutation. The combination treatment was associated with poor activity with $8 \%$ achieving a partial response $(n=1), 25 \%$ having stable disease $(n=3)$, and $17 \%$ having a PFS of $>6$ months $(n=2)$.

Another notable strategy has been combination therapy with anti-angiogenic and PD-1/PD-L1 inhibitors [87]. The rationale behind this approach is to dampen the immunosuppressive tumor microenvironment to enhance the immune response. VEGF blockade increases immune cell infiltrate through the promotion of T-cell trafficking thereby decreasing the ratio of MDSCs and Tregs. The combination of the anti-PD-L1 antibody atezolizumab with bevacizumab was shown to reduce the progression of platinum-resistant $\mathrm{OC}$ in vivo through the suppression of epithelial-mesenchymal transition [87].

A phase 2 study investigated combination treatment with nivolumab and bevacizumab and recruited 38 patients of which $18(47 \%)$ had platinum-resistant disease [88]. The ORR in the trial population was $28.9 \%(95 \% \mathrm{CI}, 15.4-45.9 \%)$ with a much higher ORR of $40 \%$ (95\% CI, 19.1-64.0\%) in platinum-sensitive patients compared with $16.7 \%$ (95\% CI, $3.6-41.4 \%$ ) in platinum-resistant patients. Interestingly, the proportion of patients with PD-L1 positive tumors was higher amongst platinum-resistant patients and so this cannot account for the difference in activity observed. It is difficult to interpret the data with immune-agents plus anti-vascular drugs (and in general with combination therapies) from uncontrolled clinical and/or single-arm trials, what agent provided a benefit, and if the combination is truly synergistic. Anti-vascular agents alone, in fact, can provide some benefit in patients with OC, as previously discussed. Such a question can find an answer only in controlled randomized clinical trials, and should not prompt over-enthusiastic conclusions, as well as discourage the design of clinical trials of the combination regimens without arms enrolling to single agents, as control.

Dual blockade with the checkpoint inhibitors ipilimumab and nivolumab [93] has demonstrated increased anti-tumor activity compared to either single agent alone in other tumor types where it is a standard of care treatment option. Both of these agents exert their effects through distinct pathways during $\mathrm{T}$ cell activation and therefore a combination strategy is justified. The recently published phase II randomized NRG oncology study recruited patients with a PFI of $<12$ months and included 100 patients. Most patients had platinum-resistant disease: $63.3 \%$ in the nivolumab monotherapy arm and $60.8 \%$ in the ipilimumab/nivolumab combination arm. The ORR within 6 months was significantly higher in the combination arm ( $31.4 \%$ vs. $12.2 \%)$ as was the median PFS (3.9 vs. 2 months, HR, $0.528 ; 95 \%$ CI, 0.339 to $0.821 ; p=0.004$ ). However, combination treatment did not result in a statistically significant increase in OS, and toxicity was higher as expected but comparable to previous reports (grade 3 treatment-related AEs: $49 \%$ vs. 33\%). An exploratory analysis revealed that poor prognostic markers including platinum resistance, worse performance status, older age, more previous lines of therapy, obesity, and higher baseline tumor burden favored the combination arm.

The combination of chemotherapy and immunotherapy is another strategy under investigation. Chemotherapy induces an immune-mediated mechanism of tumor-killing (immunogenic death). Anthracyclines, taxanes, and platinum compounds can activate antineoplastic immune responses, enhancing the recognition of the altered self-material [94]. However, the use of the hypomethylating agent (guadecitabine), to prime and enhance tumor cell recognition by CD8+ cells, before treatment with pembrolizumab only resulted in poor anti-tumor activity in patients with platinum-resistant OC [95]. Interestingly, preliminary data suggest that neoadjuvant platinum-based chemotherapy has an impact on 
the immune cell composition of OC [89]. Following platinum-based chemotherapy, there was a significant increase in CD4+ $(p=0.03)$ and CD8+ infiltration $(p=0.009)$ and a decrease in FOXP3+ cells $(p=0.01)$. This provides further supporting evidence for combining chemotherapy with ICIs. However, the results of the randomized, phase III, JAVELIN 200 trial [89] were presented at the Society of Gynecologic Oncology 2019 meeting and included 566 patients with platinum-resistant ovarian cancer (25\% platinum-refractory), were disappointing. Patients were randomized to avelumab, liposomal doxorubicin, or a combination of the two. The combination arm was not associated with any significant survival benefit. Interestingly, there was a higher ORR in the combination arm amongst the PDL1 positive subgroup (18.5\%, 95\% CI 11.1-27.9) compared to the PDL1 negative subgroup (3.4\%, 95\% CI 0.4-11.9). There was also a trend towards an improvement in PFS (3.7 vs. 3.0 months, HR $0.65,95 \%$ CI $0.46-0.92)$ and OS (17.7 vs. 13.1 months, HR $0.72,95 \%$ CI 0.48-1.08) when the combination treatment was compared to liposomal doxorubicin alone in PDL1 positive patients which accounted for $57 \%$. We need to better understand which patients are most likely to benefit from particular treatment strategies.

\subsection{Identification of Biomarkers of Immune-Response}

Along with efforts to improve therapeutic outcomes by evaluating combination strategies, there is a strong need for biomarkers to guide patient selection. Evidence suggests that response to immunotherapy might be higher in certain subtypes of OC. For example, $\sim 10 \%$ of clear cell tumors are MSI-H, and consequently, show higher PD-1 expression rates compared to their serous counterparts [90]. Similarly, mutations in BRCA1/2 and TP53, which confer a significant lifetime risk for ovarian carcinoma, correlate with a higher neoantigen load [91]. In patients with OC, both BRCA1/2 and TP53 mutation status correlate with increased PD-1/PD-L1 expression levels, and they might therefore be more likely to respond to immunotherapy [92]. High PD-1/PD-L1 expression on tumor cells and TILs has been associated with a favorable prognosis in HGSC [96].

Several biomarkers of response to immunotherapy, which have been studied in other solid tumors, have also been investigated in OC and are described in detail below:

1. PD-L1: PD-L1 expression, assessed through immune-histochemistry techniques, has been investigated as a biomarker to predict response to anti-PD1 therapy in several tumors. In some cases, the indication for immunotherapy either as a single agent or in combination with other agents depends on the degree of PD-L1 expression on tumor tissue (e.g., NSCLC). In HGSC, PD-L1 expression has been reported in $90 \%$ of cases, with 30\% deemed to have a high expression of the biomarker [91,92]. However, to date the data regarding the role of PD-L1 as a marker to predict response to immunotherapy in HGSC are inconsistent. Moreover, different methods to define PDL1 status have been used across studies which makes interpreting the overall value of this potential biomarker more challenging [91].

2. TILs: As discussed, the presence of abundant TILs in tumor tissue is associated with favorable clinical outcomes in several solid tumors including HGSC [97-99]. TILs modulate the tracking and response to neoantigens and play a role in reducing resistance to platinum compounds. However, the presence of abundant TILs per se is not sufficient to predict response to immunotherapy, since different mechanisms acting in tumor cells and within the TME can affect the action of TILs and reduce the immune response [98]. Moreover, recent evidence from multi-region analysis of metastatic sites suggests that even a single metastatic site with relative immune privilege may lead to treatment resistance despite immune response elsewhere [99].

3. TMB: TMB is defined as the total number of somatic coding mutations in a tumor. Highly mutated tumors are more likely to produce tumor-specific epitopes, acting as neoantigens that are recognized as non-self by the immune system [100]. Tumors with an increased TMB are potentially more immunogenic and may therefore benefit from immunotherapy. A correlation between high TMB and improved clinical response in HGSC has been reported as well [101]. A retrospective analysis revealed that 
the presence of BRCA mutations and high TMB was associated with longer OS in patients with HGSC [101]. However, prospective data confirming the role of TMB as a potential biomarker are still awaited. Results of the phase II trial KEYNOTE-158 (NCT02628067), which investigated the use of pembrolizumab in patients with solid tumors and high TMB, provide preliminary data in this setting. The Food and Drug Administration (FDA) has recently approved the supplemental Biologics License Application for pembrolizumab as treatment of adult and pediatric patients with unresectable or metastatic solid tumors with high TMB (i.e., >10 mutations/ $\mathrm{Mb}$ ) [99].

In the context of platinum-resistant HGSC, the most compelling evidence is the interplay between genetic instability and immune response, which supports the combination of drugs targeting DNA repair processes and immunotherapy as the most promising future combination strategy. However, none of the biomarkers here presented have been prospectively validated in controlled clinical trials and none is prime time for clinical use. Therefore, validation in the context of randomized controlled clinical trials is warranted.

\subsection{Clear Cell Ovarian Carcinoma}

Clear-cell ovarian carcinoma (CCOC) represents a distinct entity of OC, associated with a unique clinical and genetic pattern [102] When diagnosed in the early stage, CCOC is generally associated with a better prognosis than HGSC; however, in the advanced setting, the prognosis of CCOC is dismal, with poor response to standard treatments [102] The genomic landscape of CCOC is characterized by recurrent pathogenic dysregulation of the PIK3CA-AKT-PTEN-mTOR pathway in nearly half of all cases. CCOC may occur in the context of Lynch syndrome, most commonly as a result of the germline mutations MSH2 and MLH1 [103]. Besides, half of CCOC present deleterious ARID1A mutations, which is a suggested mechanism of resistance to multiple anticancer agents associated with response to various immunotherapy agents. In experimental models, ARID1A mutated CCOC has a higher TMB with increased TILs and enhanced susceptibility to anti-PDL-1 [104] However, no study molecularly-selecting for this subtype of patients has been reported. Subgroup analysis from the KEYNOTE-100 clinical trial showed an improved response in patients with CCOC ( $n=19$ patients), with an ORR of 15.8\% (CI 95\% 3.4-39.6), with one complete response [79]. Though not statistically significant for this small population, the survival analysis showed a trend towards an improved OS for CCOC, suggesting that immunotherapy should be further investigated in this setting. The NRG Oncology [93] study also provided further support for immunotherapy as patients with CCOC (12\% of the study population) had fivefold odds of response compared to other histologic subtypes. Taken together, this tiny corpus of evidence should be carefully viewed and considered no more than anectodical reports. It is nebulous whether the clear cell histology is the determinant of the immunogenicity or more likely such a benefit is driven by the MSI status, that is enriched in this subtype of OC.

To date, several clinical trials of immunotherapy for patients with CCOC are ongoing, but none have been reported. Interestingly, one study is investigating the role of nivolumab with or without ipilimumab for the treatment of advanced extra-renal clear cell carcinomas (NCT03355976), based on the concept that the tumorigenesis of clear cell variants may confer immunogenic properties [105]. Both renal and ovarian clear cell carcinomas present common alterations of the DNA remodeling complex SWI-SNF, as well as PI3K-mTOR dysregulations, suggesting that drug development might be tumor agnostic for the clear cell histotype.

Pending the results of ongoing clinical trials, a significant proportion of CCOC patients will be eligible for immunotherapy with pembrolizumab, based on the approved indication of MMR deficient neoplasms and/or tumors with high TMB-of which CCCOs seem to be enriched [106]. 


\section{Future Directions for Immune Checkpoint Inhibitor Combinations in Platinum-Resistant or Refractory OC}

Most ongoing clinical trials include anti-PD-1/PD-L1 antibodies as backbone ICIs [107-109] (Table 2). Due to a strong rationale, combination therapy with immunotherapy and PARP inhibitors continues to be of interest with three clinical trials underway: the MOONSTONE trial (NCT03955471), the BOLD trial (NCT04015739), and the OPAL trial (NCT03574779). Interestingly, the combination of immunotherapy with tyrosine kinase inhibitor (TKI) seems associated with promising results (as reported in the phase II LEAP trial). Similar to the rationale behind immunotherapy and PARP inhibitor combinations, radiotherapy can also induce DNA damage and modulate the TME. The combination of immunotherapy with radiotherapy as a possible treatment strategy has been extensively reviewed elsewhere.

Table 2. Ongoing clinical trials of immune-check point inhibitors in recurrent platinum-resistant ovarian cancer.

\begin{tabular}{|c|c|c|c|c|c|}
\hline $\begin{array}{l}\text { Experimental } \\
\text { Regimens }\end{array}$ & ICI Target & $\begin{array}{c}\text { Biomarkers for Patient } \\
\text { Selection }\end{array}$ & $\begin{array}{l}\text { Exploratory } \\
\text { Biomarkers of } \\
\text { Benefit }\end{array}$ & Phase & NCT Identifier \\
\hline Camrelizumab, apatinib. & PD-1 & - & - & 2 & NCT04068974 \\
\hline $\begin{array}{l}\text { Dostarlimab (TSR-042), } \\
\text { niraparib }\end{array}$ & PD-1 & - & - & 2 & $\begin{array}{c}\text { NCT03955471 } \\
\text { (MOONSTONE) }\end{array}$ \\
\hline $\begin{array}{l}{ }^{*} \text { multiple arms of } \\
\text { durvalumab combinations }\end{array}$ & PD-L1 & HDR, other * & - & 2 & $\begin{array}{l}\text { NCT03699449 } \\
\text { (AMBITION) }\end{array}$ \\
\hline $\begin{array}{l}\text { Pembrolizumab, } \\
\text { chemotherapy }\end{array}$ & PD-1 & - & PD-L1 & 2 & $\begin{array}{l}\text { NCT03539328 } \\
\text { (MITO27) }\end{array}$ \\
\hline Pembrolizumab, Lenvatinib & PD-1 & - & PD-L1 & 2 & $\begin{array}{l}\text { NCT03797326 } \\
\text { (LEAP-005) }\end{array}$ \\
\hline $\begin{array}{c}\text { Durvalumab, } \\
\text { TPIV200/huFR-1 \# }\end{array}$ & PD-L1 & - & - & 2 & NCT02764333 \\
\hline $\begin{array}{c}\text { Atezolizumab, } \\
\text { Bevacizumab, ASA }\end{array}$ & PD-L1 & - & - & 2 & NCT02659384 \\
\hline $\begin{array}{c}\text { Atezolizumab, } \\
\text { Bevacizumab, cobimetinib }\end{array}$ & PD-L1 & - & - & 2 & $\begin{array}{l}\text { NCT03363867 } \\
\text { (BEACON) }\end{array}$ \\
\hline Durvalumab, AVB-S6-500 & PD-L1 & - & $\begin{array}{l}\text { phenotypic } \\
\text { change in } \\
\text { immune-cells }\end{array}$ & $1 / 2$ & NCT04019288 \\
\hline Utomilumab ** & 4-1BB (CD137) & $\begin{array}{ll}\text { - } & \text { PRAME, COL6A3 } \\
\text { (CAA) } \\
\text { - } & \text { HLA-A *0201 (HLA) }\end{array}$ & - & 1 & NCT03318900 \\
\hline $\begin{array}{c}\text { Durvalumab, Bevacizumab, } \\
\text { Olaparib }\end{array}$ & PD-L1 & - & TMB, HR, TII & 2 & $\begin{array}{l}\text { NCT04015739 } \\
\text { (BOLD) }\end{array}$ \\
\hline $\begin{array}{l}\text { Dostarlimab (TSR-042), } \\
\text { niraparib, bevacizumab }\end{array}$ & PD-1 & - & - & 2 & $\begin{array}{l}\text { NCT03574779 } \\
\text { (OPAL) }\end{array}$ \\
\hline Durvalumab, ONCOS-102 & PD-L1 & - & - & $1 / 2$ & NCT02963831 \\
\hline Durvalumab, azacitidine & PD-L1 & - & - & 2 & $\begin{array}{l}\text { NCT02811497 } \\
\text { (METADUR) \$ }\end{array}$ \\
\hline $\begin{array}{l}\text { Durvalumab, focal } \\
\text { radiotherapty }{ }^{\wedge}\end{array}$ & PD-L1 & - & - & 1 & NCT03283943 \\
\hline Pembrolizumab, ENB003 & PD-1 & - & PD-L1, ETBR & $1 / 2$ & NCT04205227 \\
\hline $\begin{array}{c}\text { Emactuzumab, } \\
\text { bevacizumab, Paclitaxel }\end{array}$ & CSF1R & - & $\begin{array}{c}\text { Radiomic } \\
\text { parameters \#\# }\end{array}$ & 2 & NCT02923739 \\
\hline
\end{tabular}


Table 2. Cont.

\begin{tabular}{|c|c|c|c|c|c|}
\hline $\begin{array}{l}\text { Experimental } \\
\text { Regimens }\end{array}$ & ICI Target & $\begin{array}{c}\text { Biomarkers for Patient } \\
\text { Selection }\end{array}$ & $\begin{array}{c}\text { Exploratory } \\
\text { Biomarkers of } \\
\text { Benefit }\end{array}$ & Phase & NCT Identifier \\
\hline $\begin{array}{c}\text { Nivolumab, } \\
\text { Pembrolizumab, DSP-7888 }\end{array}$ & PD-1 & $\begin{array}{l}\text { HLA-A* 02:01, } \\
\text { HLA-A* 02:06, } \\
\text { HLA-A*24:02 }^{*}\end{array}$ & - & $1 / 2$ & NCT03311334 \\
\hline $\begin{array}{l}\text { Avelumab, TRX518, } \\
\text { Cyclophosphamide }\end{array}$ & PD-L1, GITR & - & - & $1 / 2$ & NCT03861403 \\
\hline
\end{tabular}

Immune-checkpoint inhibitors (ICI) are reported in italic. Data extracted from Clinicaltrial.gov (last access 23 March 2020). PD-1, programmed death 1. PD-L1, programmed death-ligand 1. HDR, Homologous Recombination Deficiency. ASA, acetyl salicylic acid. CCA, cancer-associated antigens. HLA, Human Leucocyte Antigen. TMB, Tumour Mutational Burden. HR, Homologous recombination status. TII, tumour immune infiltrate. ENB003, Endothelin B Receptor Antagonist. ETBR, Endothelin B Receptor. CSF1R, Colony stimulating factor 1 receptor. DSP-7888, WT1 protein-derived peptide vaccine. GITR, glucocorticoid-induced TNFR-related protein. PRAME, Melanoma antigen preferentially expressed in tumors. COL6A3, collagen type VI alpha 3 chain. * umbrella Study of Biomarker-driven Targeted Therapy with olaparib + cediranib or durvalumab + olaparib or durvalumab + chemotherapy or durvalumab + tremelimumab + chemotherapy or durvalumab + tremelimumab + paclitaxel treatment. The study enrolls patients to PAPR-inhibitors combination treatments if HDR tumors or other biomarker-based allocation (not specified) for non-HDR tumors. \# Multi-Epitope Anti-Folate Receptor Vaccine ${ }^{\wedge}$ changes in T cell populations (including but not limited to CD3, CD8, CD4, FOXP3) and cell proliferation and changes in the proportion of macrophage phenotypes M1 and M2 (with phenotypic markers potentially including arginase1, CD11b, PDL-1, and CD206) ** adoptive immunotherapy with transferred central memory-type CTL targeting ovarian cancer antigens administered alone, and in combination with, utomilumab $\sim$ ONCOS-102 is an oncolytic adenovirus armed with human GM-CSF and an Ad5/3 chimeric capsid. \$ Basket Study, ${ }^{\wedge} 24$ Gray (6 Gy $X 4$ fractions), may be escalated to 32 Gy (8 Gy per 4 fractions). \#\# non-invasive imaging macrophage-specific imaging, ADC (apparent diffusion coefficient) for cellularity, and DCE (dynamic contrast enhanced) for vasculature.

Results from studies combining two drugs have not been as successful as anticipated. Therefore the triple combination strategy of chemotherapy, immunotherapy, and targeted agents (either PARP or VEGF inhibitors) is currently under investigation in several ongoing trials [109]. Immunotherapy with agents targeting the mitogen-activated protein kinases (MAPKs) pathway, which is dysregulated in $3-11 \%$ of OC patients, is another strategy that has gained interest $[110,111]$. The immunomodulatory impact of MAPK inhibition has been demonstrated in a wide range of tumors [111]. Several studies have shown that MEK inhibitors increase the expression of intrinsic and IFN- $\gamma$-induced HLA/MHC I and II in cancer cells, and the number of CD8+ TILs [111]. The combination of MEK inhibitors with ICIs is under investigation. The BEACON trial (NCT03363867) is currently ongoing to assess the efficacy and safety of an anti-PD-L1 monoclonal antibody combined with a MEK-inhibitor and an anti-VEGF monoclonal antibody. Notably, the majority of the ongoing trials are designed and sponsored by companies, and few explore therapies based on early clinical or preclinical evidence matured in independent research contexts. This can introduce some elements of bias in the design, data reporting, and interpretation of the results, including in the selection of the regimens in the control arms (when is not a placebo) or the declination of the medical unmet needs into uncontrolled studies-the ones that leave ample margins of uncertainties and more often expose patients to therapies with doubtful value. This has wide potential consequences, from suboptimal clinical care driven by hyped results to broader societal harms.

Given the immunosuppressive tumor micro-environment in platinum-resistant OC and the poor benefit observed with single immunotherapy agents, most current research focuses on enhancing immunotherapy response with the use of combination treatments. Although beyond the scope of this review, it is important to note that other immunotherapy strategies under investigation include adoptive cell therapy and vaccines. Evidence from ongoing clinical trials will hopefully change the treatment paradigm of platinum-resistant disease in the next future.

\section{Conclusions}

Evidence from pre-clinical and clinical studies suggests that at least a subgroup of OC patients show a pro-active immune contexture, favoring a response to immunotherapy, either alone or in combination with other agents. However, to date, there are no established biomark- 
ers to select OC patients that are likely to respond to immunotherapy. Available data on the prognostic and predictive significance of PD-1 and PD-L1 expression, as well as the presence of TILs, in OC, are inconsistent. Prospective controlled trials are currently underway to identify potential biomarkers of response or resistance to immunotherapy. Treatment options remain limited for patients with platinum-resistant OC. Therefore, clinical trials that aim to identify key drivers of immune-response and optimize patient selection to improve future outcomes should be considered a priority. Presently, the only place for immune-checkpoint inhibitors in platinum-resistant OC is through well-designed clinical trials.

Author Contributions: A.I.; G.B.; F.R., S.L., D.T. coordinated the work and produced the first outline. All the authors provided input and refined the working plan. C.G.L.; S.L., G.B.; O.N. provided in-depth insights on the tumor biology and immunobiology. A.I.; S.K.; S.L., F.R. D.T. extracted the data from completed and ongoing clinical trials from the online datasets. A.P.; S.L., G.B.; M.G.; F.R., S.K. improved the paper formatting and text flow. All the authors contributed to the writing, developed single paragraphs and approved the final draft. All authors have read and agreed to the published version of the manuscript.

Funding: This research received no external funding.

Institutional Review Board Statement: Not applicable.

Informed Consent Statement: Not applicable.

Acknowledgments: We would like to thank Erika Rijavec, medical oncologist at the Fondazione IRCCS Ca' Granda Ospedale Maggiore Policlinico, Milan (Italy) for providing constructive feedback on the outline of the present work and on an early proof of the manuscript.

Conflicts of Interest: D.T.; A.I.; M.G.; S.K.; G.B. have no COI to disclose. A.P. reports personal fees from Eli Lilly, outside the submitted work. C.G.L. reports employment by Bristol Myers Squibb.

\section{References}

1. Bray, F.; Ferlay, J.; Soerjomataram, I.; Siegel, R.L.; Torre, L.A.; Jemal, A. Global cancer statistics 2018: GLOBOCAN estimates of inci-dence and mortality worldwide for 36 cancers in 185 countries. CA Cancer J. Clin. 2018, 68, 394-424. [CrossRef] [PubMed]

2. Siegel, R.L.; Miller, K.D.; Jemal, A. Cancer statistics, 2020. CA Cancer J. Clin. 2020, 70, 7-30. [CrossRef] [PubMed]

3. Noone, A.M.; Howlader, N.; Krapcho, M.; Miller, D.; Brest, A.; Yu, M.; Ruhl, J.; Tatalovich, Z.; Mariotto, A.; Lewis, D.R.; et al. SEER Can-cer Statistics Review, 1975-2015, National Cancer Institute. Bethesda, MD. Available online: https://seer.cancer.gov / csr/1975_2017/ (accessed on 1 April 2021).

4. Raspagliesi, F.; Bogani, G.; Benedetti, S.; Grassi, S.; Ferla, S.; Buratti, S. Detection of Ovarian Cancer through Exhaled Breath by Electronic Nose: A Prospective Study. Cancers 2020, 12, 2408. [CrossRef] [PubMed]

5. Duska, L.R.; Kohn, E.C. The new classifications of ovarian, fallopian tube, and primary peritoneal cancer and their clinical im-plications. Ann. Oncol. 2017, 28, viii8-viii12. [CrossRef]

6. Kelly, P.N. The Cancer Immunotherapy Revolution. Science 2018, 359, 1344-1345. [CrossRef] [PubMed]

7. Rocconi, R.P.; Grosen, E.A.; Ghamande, S.A.; Chan, J.K.; Barve, M.A.; Oh, J.; Tewari, D.; Morris, P.C.; Stevens, E.E.; BottsfordMiller, J.N.; et al. Gemogenovatucel-T (Vigil) immunotherapy as maintenance in frontline stage III/IV ovarian cancer (VITAL): A random-ised, double-blind, placebo-controlled, phase 2b trial. Lancet Oncol. 2020, 21, 1661-1672. [CrossRef]

8. Wilson, M.K.; Pujade-Lauraine, E.; Aoki, D.; Mirza, M.R.; Lorusso, D.; Oza, A.M.; du Bois, A.; Vergote, I.; Reuss, A.; Bacon, M.; et al. Fifth Ovarian Cancer Consensus Conference of the Gynecologic Cancer InterGroup: Recurrent disease. Ann. Oncol. 2017, 28, 727-732. [CrossRef]

9. Colombo, N.; Sessa, C.; Bois, A.D.; Ledermann, J.; McCluggage, W.G.; McNeish, I.; Morice, P.; Pignata, S.; Ray-Coquard, I.; Vergote, I.; et al. ESMO-ESGO consensus conference recommendations on ovarian cancer: Pathology and molecular biology, early and ad-vanced stages, borderline tumours and recurrent disease. Ann. Oncol. 2019, 30, 672-705. [CrossRef] [PubMed]

10. Davis, A.; Tinker, A.V.; Friedlander, M. "Platinum resistant" ovarian cancer: What is it, who to treat and how to measure bene-fit? Gynecol. Oncol. 2014, 133, 624-631. [CrossRef]

11. Freyer, G.; Ray-Coquard, I.; Fischer, D.; Martín, A.G.; Kielhorn, A.; Chia, V.; Nanayakkara, N.; Taylor, A. Routine Clinical Practice for Patients With Recurrent Ovarian Carcinoma: Results From the TROCADERO Study. Int. J. Gynecol. Cancer 2016, 26, $240-247$. [CrossRef]

12. Marth, C.; Vergote, I.; Scambia, G.; Oberaigner, W.; Clamp, A.; Berger, R.; Kurzeder, C.; Colombo, N.; Vuylsteke, P.; Lorusso, D.; et al. ENGOT-ov-6/TRINOVA-2: Randomised, double-blind, phase 3 study of pegylated liposomal doxorubicin plus trebananib or placebo in women with recurrent partially platinum-sensitive or resistant ovarian cancer. Eur. J. Cancer 2017, 70, 111-121. [CrossRef] [PubMed] 
13. Pignata, S.; Scambia, G.; Bologna, A.; Signoriello, S.; Vergote, I.B.; Wagner, U.; Lorusso, D.; Murgia, V.; Sorio, R.; Ferrandina, G.; et al. Randomized Controlled Trial Testing the Efficacy of Platinum-Free Interval Prolongation in Advanced Ovarian Cancer: The MITO-8, MaNGO, BGOG-Ov1, AGO-Ovar2.16, ENGOT-Ov1, GCIG Study. J. Clin. Oncol. 2017, 35, 3347-3353. [CrossRef] [PubMed]

14. Romero, I.; Mallol, P.; Santaballa, A.; Del Campo, J.M.; Mori, M.; González-Santiago, S.; Casado, A.; Vicente, D.; Ortega, E.; Herrero, A.; et al. Multicenter retrospective study to evaluate the impact of trabectedin plus pegylated liposomal doxorubicin on the subsequent treatment in women with recurrent, platinum-sensitive ovarian cancer. Anticancer Drugs 2019, 30, 628-635. [CrossRef] [PubMed]

15. Pokhriyal, R.; Hariprasad, R.; Kumar, L.; Hariprasad, G. Chemotherapy Resistance in Advanced Ovarian Cancer Patients. Biomark. Cancer 2019, 11. [CrossRef]

16. Slaughter, K.; Holman, L.L.; Thomas, E.L.; Gunderson, C.C.; Lauer, J.K.; Ding, K.; McMeekin, D.S.; Moore, K.M. Primary and acquired platinum-resistance among women with high grade serous ovarian cancer. Gynecol. Oncol. 2016, 142, 225-230. [CrossRef] [PubMed]

17. Galluzzi, L.; Senovilla, L.; Vitale, I.; Michels, J.; Martins, I.; Kepp, O.; Castedo, M.; Kroemer, G. Molecular mechanisms of cisplatin re-sistance. Oncogene 2012, 31, 1869-1883. [CrossRef] [PubMed]

18. Jayson, G.C.; Kohn, E.C.; Kitchener, H.C.; Ledermann, J.A. Ovarian cancer. Lancet 2014, 384, 1376-1388. [CrossRef]

19. Luo, Q.; Wu, X.; Zhang, Y.; Shu, T.; Ding, F.; Chen, H.; Zhao, P.; Chang, W.; Zhu, X.; Liu, Z. ARID1A ablation leads to multiple drug resistance in ovarian cancer via transcriptional activation of MRP2. Cancer Lett. 2018, 427, 9-17. [CrossRef]

20. Shen, J.; Ju, Z.; Zhao, W.; Wang, L.; Peng, Y.; Ge, Z.; Nagel, Z.D.; Zou, J.; Wang, C.; Kapoor, P.; et al. ARID1A deficiency promotes muta-bility and potentiates therapeutic antitumor immunity unleashed by immune checkpoint blockade. Nat. Med. 2018, 24, 556-562. [CrossRef]

21. Chen, S.-H.; Chang, J.-Y. New Insights into Mechanisms of Cisplatin Resistance: From Tumor Cell to Microenvironment. Int. J. Mol. Sci. 2019, 20, 4136. [CrossRef]

22. Bogani, G.; Ricci, M.T.; Vitellaro, M.; Ditto, A.; Chiappa, V.; Raspagliesi, F. Impact of gene-specific germline pathogenic variants on presentation of endometrial cancer in Lynch syndrome. Int. J. Gynecol. Cancer 2019, 29, 705-710. [CrossRef] [PubMed]

23. Ledermann, J.; Kemp, Z. Update on first-line treatment of advanced ovarian carcinoma. Int. J. Womens Health 2013, 5, 45-51. [CrossRef] [PubMed]

24. Marcelis, C.L.M.; Van Der Putten, H.W.H.M.; Tops, C.; Lutgens, L.C.H.W.; Moog, U. Chemotherapy resistant ovarian cancer in carriers of an hMSH2 mutation? Fam. Cancer 2001, 1, 109-111. [CrossRef] [PubMed]

25. Plumb, J.A.; Strathdee, G.; Sludden, J.; Kaye, S.B.; Brown, R. Reversal of drug resistance in human tumor xenografts by 2'-deoxy-5-azacytidine-induced demethylation of the hMLH1 gene promoter. Cancer Res. 2000, 60, 6039-6044. [PubMed]

26. Rocha, C.R.R.; Silva, M.M.; Quinet, A.; Cabral-Neto, J.B.; Menck, C.F.M. DNA repair pathways and cisplatin resistance: An intimate relationship. Clinics 2018, 73, e478s. [CrossRef] [PubMed]

27. Strathdee, G.; MacKean, M.J.; Illand, M.; Brown, R. A role for methylation of the hMLH1 promoter in loss of hMLH1 expression and drug resistance in ovarian cancer. Oncogene 1999, 18, 2335-2341. [CrossRef] [PubMed]

28. Xiao, X.; Melton, D.W.; Gourley, C. Mismatch repair deficiency in ovarian cancer - molecular characteristics and clinical impli-cations. Gynecol. Oncol. 2014, 132, 506-512. [CrossRef]

29. Zeller, C.; Dai, W.; Steele, N.L.; Siddiq, A.; Walley, A.J.; Wilhelm-Benartzi, C.S.; Rizzo, S.; van der Zee, A.; Plumb, J.A.; Brown, R. Candi-date DNA methylation drivers of acquired cisplatin resistance in ovarian cancer identified by methylome and expression pro-filing. Oncogene 2012, 31, 4567-4576. [CrossRef]

30. Albertella, M.R.; Lau, A.; O'Connor, M.J. The overexpression of specialized DNA polymerases in cancer. DNA Repair 2005, 4, 583-593. [CrossRef]

31. Boudsocq, F.; Benaim, P.; Canitrot, Y.; Knibiehler, M.; Ausseil, F.; Capp, J.P.; Bieth, A.; Long, C.; David, B.; Shevelev, I.; et al. Modulation of cellular response to cisplatin by a novel inhibitor of DNA polymerase beta. Mol. Pharmacol. 2005, 67, 1485-1492. [CrossRef]

32. Sasatani, M.; Zaharieva, E.K.; Kamiya, K. The in vivo role of Rev1 in mutagenesis and carcinogenesis. Genes Environ. 2020, 42, 1-5. [CrossRef] [PubMed]

33. Srivastava, A.K.; Han, C.; Zhao, R.; Cui, T.; Dai, Y.; Mao, C.; Zhao, W.; Zhang, X.; Yu, J.; Wang, Q.-E. Enhanced expression of DNA polymerase eta contributes to cisplatin resistance of ovarian cancer stem cells. Proc. Natl. Acad. Sci. USA 2015, 112, $4411-4416$. [CrossRef] [PubMed]

34. Cancer Genome Atlas Research Network. Integrated genomic analyses of ovarian carcinoma. Nature 2011, 474, 609-615. [CrossRef]

35. Alsop, K.; Fereday, S.; Meldrum, C.; DeFazio, A.; Emmanuel, C.; George, J.; Dobrovic, A.; Birrer, M.J.; Webb, P.M.; Stewart, C.; et al. BRCA Mutation Frequency and Patterns of Treatment Response in BRCA Mutation-Positive Women With Ovarian Cancer: A Report From the Australian Ovarian Cancer Study Group. J. Clin. Oncol. 2012, 30, 2654-2663. [CrossRef]

36. Walsh, T.; Casadei, S.; Lee, M.K.; Pennil, C.C.; Nord, A.S.; Thornton, A.M.; Roeb, W.; Agnew, K.J.; Stray, S.M.; Wickramanayake, A.; et al. Mutations in 12 genes for inherited ovarian, fallopian tube, and peritoneal carcinoma identified by massively parallel se-quencing. Proc. Natl. Acad. Sci. USA 2011, 108, 18032-18037. [CrossRef] 
37. Dai, Y.; Sun, C.; Feng, Y.; Jia, Q.; Zhu, B. Potent immunogenicity in BRCA1-mutated patients with high-grade serous ovarian car-cinoma. J. Cell Mol. Med. 2018, 22, 3979-3986. [CrossRef]

38. Shen, D.W.; Pouliot, L.M.; Hall, M.D.; Gottesman, M.M. Cisplatin resistance: A cellular self-defense mechanism resulting from mul-tiple epigenetic and genetic changes. Pharmacol. Rev. 2012, 64, 706-721. [CrossRef]

39. Li, H.; Li, J.; Gao, W.; Zhen, C.; Feng, L. Systematic analysis of ovarian cancer platinum-resistance mechanisms via text mining J. Ovarian Res. 2020, 13, 1-6. [CrossRef]

40. Yao, J.; Gong, Y.; Zhao, W.; Han, Z.; Guo, S.; Liu, H.; Peng, X.; Xiao, W.; Li, Y.; Dang, S.; et al. Comprehensive analysis of POLE and POLD1 Gene Variations identifies cancer patients potentially benefit from immunotherapy in Chinese population. Sci. Rep. 2019, 9, 15767. [CrossRef]

41. Mutch, D.G.; Orlando, M.; Goss, T.; Teneriello, M.G.; Gordon, A.N.; McMeekin, S.D.; Wang, Y.; Scribner, D.R.; Marciniack, M.; Naumann, R.W.; et al. Randomized Phase III Trial of Gemcitabine Compared with Pegylated Liposomal Doxorubicin in Patients With Platinum-Resistant Ovarian Cancer. J. Clin. Oncol. 2007, 25, 2811-2818. [CrossRef] [PubMed]

42. ten Bokkel Huinink, W.; Gore, M.; Carmichael, J.; Gordon, A.; Malfetano, J.; Hudson, I.; Broom, C.; Scarabelli, C.; Davidson, N.; Span-czynski, M.; et al. Topotecan versus paclitaxel for the treatment of recurrent epithelial ovarian cancer. J. Clin. Oncol. 1997, 15, 2183-2193. [CrossRef] [PubMed]

43. Poveda, A.M.; Selle, F.; Hilpert, F.; Reuss, A.; Savarese, A.; Vergote, I.; Witteveen, P.; Bamias, A.; Scotto, N.; Mitchell, L.; et al. Bevacizumab Combined With Weekly Paclitaxel, Pegylated Liposomal Doxorubicin, or Topotecan in Platinum-Resistant Recurrent Ovarian Cancer: Analysis by Chemotherapy Cohort of the Randomized Phase III AURELIA Trial. J. Clin. Oncol. 2015, 33, 3836-3838. [CrossRef] [PubMed]

44. Richardson, D.L.; Sill, M.W.; Coleman, R.L.; Sood, A.K.; Pearl, M.L.; Kehoe, S.M.; Carney, M.E.; Hanjani, P.; Van Le, L.; Zhou, X.C.; et al. Paclitaxel With and Without Pazopanib for Persistent or Recurrent Ovarian Cancer: A Randomized Clinical Trial. JAMA Oncol. 2018, 4, 196-202. [CrossRef] [PubMed]

45. Hirte, H.; Lheureux, S.; Fleming, G.; Sugimoto, A.; Morgan, R.; Biagi, J.; Wang, L.; McGill, S.; Ivy, S.; Oza, A. A phase 2 study of cediranib in recurrent or persistent ovarian, peritoneal or fallopian tube cancer: A trial of the Princess Margaret, Chicago and California Phase II Consortia. Gynecol. Oncol. 2015, 138, 55-61. [CrossRef]

46. Simsek, C.; Esin, E.; Yalcin, S. Metronomic Chemotherapy: A Systematic Review of the Literature and Clinical Experience. J. Oncol. 2019, 2019, 1-31. [CrossRef]

47. Ferrandina, G.; Corrado, G.; Mascilini, F.; Malaguti, P.; Samaritani, R.; Distefano, M.; Masciullo, V.; Di Legge, A.; Savarese, A.; Scambia, G. Metronomic oral cyclophosphamide (MOC) in the salvage therapy of heavily treated recurrent ovarian cancer patients: A retrospective, multicenter study. BMC Cancer 2014, 14, 947. [CrossRef]

48. George, A.; McLachlan, J.; Tunariu, N.; Della Pepa, C.; Migali, C.; Gore, M.; Kaye, S.; Banerjee, S. The role of hormonal therapy in patients with relapsed high-grade ovarian carcinoma: A retrospective series of tamoxifen and letrozole. BMC Cancer 2017, 17, 1-8. [CrossRef]

49. Santoiemma, P.P.; Powell, D.J. Tumor infiltrating lymphocytes in ovarian cancer. Cancer Biol. Ther. 2015, 16, 807-820. [CrossRef]

50. Santoiemma, P.P.; Reyes, C.; Wang, L.-P.; McLane, M.W.; Feldman, M.D.; Tanyi, J.L.; Powell, D.J. Systematic evaluation of multiple immune markers reveals prognostic factors in ovarian cancer. Gynecol. Oncol. 2016, 143, 120-127. [CrossRef]

51. Stumpf, M.; Hasenburg, A.; Riener, M.O.; Jütting, U.; Wang, C.; Shen, Y.; Orlowska-Volk, M.; Fisch, P.; Wang, Z.; Gitsch, G.; et al. In-traepithelial CD8-positive T lymphocytes predict survival for patients with serous stage III ovarian carcinomas: Relevance of clonal selection of T lymphocytes. Br. J. Cancer 2009, 101, 1513-1521. [CrossRef]

52. Zhang, L.; Conejo-Garcia, J.R.; Katsaros, D.; Gimotty, P.A.; Massobrio, M.; Regnani, G.; Makrigiannakis, A.; Gray, H.; Schlienger, K.; Liebman, M.N.; et al. Intratumoral T cells, recurrence, and survival in epithelial ovarian cancer. N. Engl. J. Med. 2003, 348, 203-213. [CrossRef] [PubMed]

53. Sato, E.; Olson, S.H.; Ahn, J.; Bundy, B.; Nishikawa, H.; Qian, F.; Jungbluth, A.A.; Frosina, D.; Gnjatic, S.; Ambrosone, C.; et al. Intraepi-thelial CD8+ tumor-infiltrating lymphocytes and a high CD8+/regulatory $\mathrm{T}$ cell ratio are associated with favorable prognosis in ovarian cancer. Proc. Natl. Acad. Sci. USA 2005, 102, 18538-18543. [CrossRef]

54. Hwang, W.-T.; Adams, S.F.; Tahirovic, E.; Hagemann, I.S.; Coukos, G. Prognostic significance of tumor-infiltrating T cells in ovarian cancer: A meta-analysis. Gynecol. Oncol. 2012, 124, 192-198. [CrossRef] [PubMed]

55. Nielsen, J.S.; Sahota, R.A.; Milne, K.; Kost, S.E.; Nesslinger, N.J.; Watson, P.H.; Nelson, B.H. CD20+ Tumor-Infiltrating Lymphocytes Have an Atypical CD27- Memory Phenotype and Together with CD8+ T Cells Promote Favorable Prognosis in Ovarian Cancer. Clin. Cancer Res. 2012, 18, 3281-3292. [CrossRef] [PubMed]

56. Rodriguez, G.M.; Galpin, K.J.C.; McCloskey, C.W.; Vanderhyden, B.C. The Tumor Microenvironment of Epithelial Ovarian Cancer and Its Influence on Response to Immunotherapy. Cancers 2018, 10, 242. [CrossRef] [PubMed]

57. Hanahan, D.; Coussens, L.M. Accessories to the crime: Functions of cells recruited to the tumor microenvironment. Cancer Cell 2012, 21, 309-322. [CrossRef]

58. Mittal, D.; Gubin, M.M.; Schreiber, R.D.; Smyth, M.J. New insights into cancer immunoediting and its three component phas-eselimination, equilibrium and escape. Curr. Opin. Immunol. 2014, 27, 16-25. [CrossRef]

59. Cohen, C.A.; Shea, A.A.; Heffron, C.L.; Schmelz, E.M.; Roberts, P.C. Interleukin-12 Immunomodulation Delays the Onset of Lethal Peritoneal Disease of Ovarian Cancer. J. Interf. Cytokine Res. 2016, 36, 62-73. [CrossRef] 
60. Koneru, M.; Purdon, T.J.; Spriggs, D.; Koneru, S.; Brentjens, R.J. IL-12 secreting tumor-targeted chimeric antigen receptor T cells eradicate ovarian tumorsin vivo. OncoImmunology 2015, 4, e994446. [CrossRef]

61. Kusuda, T.; Shigemasa, K.; Arihiro, K.; Fujii, T.; Nagai, N.; Ohama, K. Relative expression levels of Th1 and Th2 cytokine mRNA are independent prognostic factors in patients with ovarian cancer. Oncol. Rep. 2005, 13, 1153-1158. [CrossRef]

62. Condamine, T.; Ramachandran, I.; Youn, J.-I.; Gabrilovich, D.I. Regulation of Tumor Metastasis by Myeloid-Derived Suppressor Cells. Annu. Rev. Med. 2015, 66, 97-110. [CrossRef] [PubMed]

63. Hodi, F.S.; Butler, M.; Oble, D.A.; Seiden, M.V.; Haluska, F.G.; Kruse, A.; Macrae, S.; Nelson, M.; Canning, C.; Lowy, I.; et al. Immunologic and clinical effects of antibody blockade of cytotoxic T lymphocyte-associated antigen 4 in previously vaccinated cancer pa-tients. Proc. Natl. Acad. Sci. USA 2008, 105, 3005-3010. [CrossRef] [PubMed]

64. Huang, R.-Y.; Eppolito, C.; Lele, S.; Shrikant, P.; Matsuzaki, J.; Odunsi, K. LAG3 and PD1 co-inhibitory molecules collaborate to limit CD8+ T cell signaling and dampen antitumor immunity in a murine ovarian cancer model. Oncotarget 2015, 6, 27359-27377. [CrossRef] [PubMed]

65. Matsuzaki, J.; Gnjatic, S.; Mhawech-Fauceglia, P.; Beck, A.; Miller, A.; Tsuji, T.; Eppolito, C.; Qian, F.; Lele, S.; Shrikant, P.; et al. Tu-mor-infiltrating NY-ESO-1-specific CD8+ T cells are negatively regulated by LAG-3 and PD-1 in human ovarian cancer. Proc. Natl. Acad. Sci. USA 2010, 107, 7875-7880. [CrossRef] [PubMed]

66. Darb-Esfahani, S.; Kunze, C.A.; Kulbe, H.; Sehouli, J.; Wienert, S.; Lindner, J.; Budczies, J.; Bockmayr, M.; Dietel, M.; Denkert, C.; et al. Prognostic impact of programmed cell death-1 (PD-1) and PD-ligand 1 (PD-L1) expression in cancer cells and tu-morinfiltrating lymphocytes in ovarian high grade serous carcinoma. Oncotarget 2016, 7, 1486-1499. [CrossRef]

67. Gatalica, Z.; Snyder, C.; Maney, T.; Ghazalpour, A.; Holterman, D.A.; Xiao, N.; Overberg, P.; Rose, I.; Basu, G.D.; Vranic, S.; et al. Pro-grammed cell death 1 (PD-1) and its ligand (PD-L1) in common cancers and their correlation with molecular cancer type. Cancer Epidemiol. Biomark. Prev. 2014, 23, 2965-2970. [CrossRef]

68. Hamanishi, J.; Mandai, M.; Ikeda, T.; Minami, M.; Kawaguchi, A.; Murayama, T.; Kanai, M.; Mori, Y.; Matsumoto, S.; Chikuma, S.; et al. Safety and Antitumor Activity of Anti-PD-1 Antibody, Nivolumab, in Patients With Platinum-Resistant Ovarian Cancer. J. Clin. Oncol. 2015, 33, 4015-4022. [CrossRef] [PubMed]

69. Aust, S.; Felix, S.; Auer, K.; Bachmayr-Heyda, A.; Kenner, L.; Dekan, S.; Meier, S.M.; Gerner, C.; Grimm, C.; Pils, D. Absence of PD-L1 on tumor cells is associated with reduced MHC I expression and PD-L1 expression increases in recurrent serous ovarian cancer. Sci. Rep. 2017, 7, 42929. [CrossRef]

70. Webb, J.R.; Milne, K.; Kroeger, D.R.; Nelson, B.H. PD-L1 expression is associated with tumor-infiltrating T cells and favorable prognosis in high-grade serous ovarian cancer. Gynecol. Oncol. 2016, 141, 293-302. [CrossRef]

71. Garcia-Lora, A.; Algarra, I.; Garrido, F. MHC class I antigens, immune surveillance, and tumor immune escape. J. Cell. Physiol. 2003, 195, 346-355. [CrossRef] [PubMed]

72. Massague, J. TGFbeta in Cancer. Cell 2008, 134, 215-230. [CrossRef] [PubMed]

73. Löb, S.; Königsrainer, A.; Rammensee, H.-G.; Opelz, G.; Terness, P. Inhibitors of indoleamine-2,3-dioxygenase for cancer therapy: Can we see the wood for the trees? Nat. Rev. Cancer 2009, 9, 445-452. [CrossRef] [PubMed]

74. Li, S.; Miner, K.; Fannin, R.; Carl Barrett, J.; Davis, B.J. Cyclooxygenase-1 and 2 in normal and malignant human ovarian epithe-lium. Gynecol. Oncol. 2004, 92, 622-627. [CrossRef]

75. Bogani, G.; Lopez, S.; Mantiero, M.; Ducceschi, M.; Bosio, S.; Ruisi, S.; Sarpietro, G.; Guerrisi, R.; Brusadelli, C.; Dell’Acqua, A.; et al. Im-munotherapy for platinum-resistant ovarian cancer. Gynecol. Oncol. 2020, 158, 484-488. [CrossRef]

76. NIH. Phase II Study of Ipilimumab Monotherapy in Recurrent Platinum-sensitive Ovarian Cancer. ClinicalTrials.gov. Available online: https: / / clinicaltrials.gov/ct2/show/NCT01611558 (accessed on 1 April 2021).

77. Brahmer, J.R.; Tykodi, S.S.; Chow, L.Q.; Hwu, W.J.; Topalian, S.L.; Hwu, P.; Drake, C.G.; Camacho, L.H.; Kauh, J.; Odunsi, K.; et al. Safety and activity of anti-PD-L1 antibody in patients with advanced cancer. N. Engl. J. Med. 2012, 366, 2455-2465. [CrossRef]

78. Varga, A.; Piha-Paul, S.; Ott, P.A.; Mehnert, J.M.; Berton-Rigaud, D.; Morosky, A.; Yang, P.; Ruman, J.; Matei, D. Pembrolizumab in pa-tients with programmed death ligand 1-positive advanced ovarian cancer: Analysis of KEYNOTE-028. Gynecol. Oncol. 2019, 152, 243-250. [CrossRef]

79. Matulonis, U.; Shapira-Frommer, R.; Santin, A.; Lisyanskaya, A.; Pignata, S.; Vergote, I.; Raspagliesi, F.; Sonke, G.; Birrer, M.; Provencher, D.; et al. Antitumor activity and safety of pembrolizumab in patients with advanced recurrent ovarian cancer: Results from the phase II KEYNOTE-100 study. Ann. Oncol. 2019, 30, 1080-1087. [CrossRef] [PubMed]

80. Nishio, S.; Matsumoto, K.; Takehara, K.; Kawamura, N.; Hasegawa, K.; Takeshima, N.; Aoki, D.; Kamiura, S.; Arakawa, A.; Kondo, E.; et al. Pembrolizumab monotherapy in Japanese patients with advanced ovarian cancer: Subgroup analysis from the KEY-NOTE-100. Cancer Sci. 2020, 111, 1324-1332. [CrossRef]

81. Disis, M.L.; Taylor, M.H.; Kelly, K.; Beck, J.T.; Gordon, M.; Moore, K.M.; Patel, M.R.; Chaves, J.; Park, H.; Mita, A.C.; et al. Efficacy and Safety of Avelumab for Patients with Recurrent or Refractory Ovarian Cancer: Phase 1b Results from the JAVELIN Solid Tumor Trial. JAMA Oncol. 2019, 5, 393-401. [CrossRef]

82. Li, A.; Yi, M.; Qin, S.; Chu, Q.; Luo, S.; Wu, K. Prospects for combining immune checkpoint blockade with PARP inhibition. J. Hematol. Oncol. 2019, 12, 1-12. [CrossRef] [PubMed] 
83. Strickland, K.C.; Howitt, B.E.; Shukla, S.A.; Rodig, S.; Ritterhouse, L.L.; Liu, J.F.; Garber, J.E.; Chowdhury, D.; Wu, C.J.; D'Andrea, A.D.; et al. Association and prognostic significance of BRCA1/2-mutation status with neoantigen load, number of tumorinfiltrating lymphocytes and expression of PD-1/PD-L1 in high grade serous ovarian cancer. Oncotarget 2016, 7, 13587-13598. [CrossRef] [PubMed]

84. Domchek, S.M.; Postel-Vinay, S.; Im, S.-A.; Park, Y.H.; Delord, J.-P.; Italiano, A.; Alexandre, J.; You, B.; Bastian, S.; Krebs, M.G.; et al. Olaparib and durvalumab in patients with germline BRCA-mutated metastatic breast cancer (MEDIOLA): An open-label, multicentre, phase 1/2, basket study. Lancet Oncol. 2020, 21, 1155-1164. [CrossRef]

85. Konstantinopoulos, P.A.; Waggoner, S.; Vidal, G.A.; Mita, M.; Moroney, J.W.; Holloway, R.; Van Le, L.; Sachdev, J.C.; ChapmanDavis, E.; Colon-Otero, G.; et al. Single-Arm Phases 1 and 2 Trial of Niraparib in Combination with Pembrolizumab in Patients with Recurrent Platinum-Resistant Ovarian Carcinoma. JAMA Oncol. 2019, 5, 1141-1149. [CrossRef] [PubMed]

86. Fumet, J.-D.; Limagne, E.; Thibaudin, M.; Truntzer, C.; Bertaut, A.; Rederstorff, E.; Ghiringhelli, F. Precision medicine phase II study evaluating the efficacy of a double immunotherapy by durvalumab and tremelimumab combined with olaparib in patients with solid cancers and carriers of homologous recombination repair genes mutation in response or stable after olaparib treatment. BMC Cancer 2020, 20, 1-10. [CrossRef]

87. Zhang, L.; Chen, Y.; Li, F.; Bao, L.; Liu, W. Atezolizumab and Bevacizumab Attenuate Cisplatin Resistant Ovarian Cancer Cells Progression Synergistically via Suppressing Epithelial-Mesenchymal Transition. Front. Immunol. 2019, 10, 867. [CrossRef] [PubMed]

88. Liu, J.F.; Herold, C.; Gray, K.P.; Penson, R.T.; Horowitz, N.; Konstantinopoulos, P.A.; Castro, C.M.; Hill, S.J.; Curtis, J.; Luo, W.; et al. As-sessment of Combined Nivolumab and Bevacizumab in Relapsed Ovarian Cancer: A Phase 2 Clinical Trial. JAMA Oncol. 2019, 5, 1731-1738. [CrossRef] [PubMed]

89. Yaniz, E.; Genestie, C.; Klein, C.; Salviat, F.; Ray-Coquard, I.L.; Joly, F.; Ferron, G.; Pujade-Lauraine, E.; Pautier, P.; Leary, A. Impact of chemotherapy alone or in combination with an anti-angiogenic on the immune tumor microenvironment (TME) of ovarian cancer: Data from the randomized CHIVA trial (a GINECO -GINEGEPS study). J. Clin. Oncol. 2020, 38, 6011. [CrossRef]

90. Willis, B.C.; Sloan, E.A.; Atkins, K.A.; Stoler, M.H.; Mills, A.M. Mismatch repair status and PD-L1 expression in clear cell carcinomas of the ovary and endometrium. Mod. Pathol. 2017, 30, 1622-1632. [CrossRef]

91. Wieser, V.; Gaugg, I.; Fleischer, M.; Shivalingaiah, G.; Wenzel, S.; Sprung, S.; Lax, S.F.; Zeimet, A.G.; Fiegl, H.; Marth, C. BRCA1/2 and TP53 mutation status associates with PD-1 and PD-L1 expression in ovarian cancer. Oncotarget 2018, 9, 17501-17511. [CrossRef]

92. Hamanishi, J.; Mandai, M.; Iwasaki, M.; Okazaki, T.; Tanaka, Y.; Yamaguchi, K.; Higuchi, T.; Yagi, H.; Takakura, K.; Minato, N.; et al. Programmed cell death 1 ligand 1 and tumor-infiltrating CD8+ T lymphocytes are prognostic factors of human ovarian can-cer. Proc. Natl. Acad. Sci. USA 2007, 104, 3360-3365. [CrossRef]

93. Zamarin, D.; Burger, R.A.; Sill, M.W.; Jr, D.J.P.; Lankes, H.A.; Feldman, M.D.; Zivanovic, O.; Gunderson, C.; Ko, E.; Mathews, C.; et al. Randomized Phase II Trial of Nivolumab Versus Nivolumab and Ipilimumab for Recurrent or Persistent Ovarian Cancer: An NRG Oncology Study. J. Clin. Oncol. 2020, 38, 1814-1823. [CrossRef]

94. Ocadlikova, D.; Lecciso, M.; Isidori, A.; Loscocco, F.; Visani, G.; Amadori, S.; Cavo, M.; Curti, A. Chemotherapy-Induced Tumor Cell Death at the Crossroads Between Immunogenicity and Immunotolerance: Focus on Acute Myeloid Leukemia. Front. Oncol. 2019, 9, 1004. [CrossRef] [PubMed]

95. Matei, D.; Ghamande, S.; Roman, L.; Secord, A.A.; Nemunaitis, J.; Markham, M.J.; Nephew, K.P.; Jueliger, S.; Oganesian, A.; Naim, S.; et al. A Phase I Clinical Trial of Guadecita-bine and Carboplatin in Platinum-Resistant, Recurrent Ovarian Cancer: Clinical, Pharmacokinetic, and Pharmacodynamic Analyses. Clin. Cancer Res. 2018, 24, 2285-2293. [CrossRef] [PubMed]

96. Kroeger, D.R.; Milne, K.; Nelson, B.H. Tumor-Infiltrating Plasma Cells Are Associated with Tertiary Lymphoid Structures, Cytolytic T-Cell Responses, and Superior Prognosis in Ovarian Cancer. Clin. Cancer Res. 2016, 22, 3005-3015. [CrossRef]

97. Wick, D.A.; Webb, J.R.; Nielsen, J.S.; Martin, S.D.; Kroeger, D.R.; Milne, K.; Castellarin, M.; Twumasi-Boateng, K.; Watson, P.H.; Holt, R.A.; et al. Surveillance of the tumor mutanome by T cells during progression from primary to recurrent ovarian cancer. Clin. Cancer Res. 2014, 20, 1125-1134. [CrossRef]

98. Zhang, A.W.; McPherson, A.; Milne, K.; Kroeger, D.R.; Hamilton, P.T.; Miranda, A.; Funnell, T.; Little, N.; de Souza, C.P.; Laan, S.; et al. Interfaces of Malignant and Immunologic Clonal Dynamics in Ovarian Cancer. Cell 2018, 173, 1755-1769.e22. [CrossRef]

99. Fancello, L.; Gandini, S.; Pelicci, P.G.; Mazzarella, L. Tumor mutational burden quantification from targeted gene panels: Major advancements and challenges. J. Immunother. Cancer 2019, 7, 183. [CrossRef]

100. Rooney, M.S.; Shukla, S.A.; Wu, C.J.; Getz, G.; Hacohen, N. Molecular and genetic properties of tumors associated with local im-mune cytolytic activity. Cell 2015, 160, 48-61. [CrossRef] [PubMed]

101. Le, D.T.; Uram, J.N.; Wang, H.; Bartlett, B.R.; Kemberling, H.; Eyring, A.D.; Skora, A.D.; Luber, B.S.; Azad, N.S.; Laheru, D.; et al. PD-1 Blockade in Tumors with Mismatch-Repair Deficiency. N. Engl. J. Med. 2015, 372, 2509-2520. [CrossRef]

102. Bogani, G.; Tagliabue, E.; Ditto, A.; Signorelli, M.; Martinelli, F.; Casarin, J.; Chiappa, V.; Dondi, G.; Maggiore, U.L.R.; Scaffa, C.; et al. Assessing the risk of pelvic and para-aortic nodal involvement in apparent early-stage ovarian cancer: A predictors- and nomogram-based analyses. Gynecol. Oncol. 2017, 147, 61-65. [CrossRef]

103. Helder-Woolderink, J.; Blok, E.; Vasen, H.; Hollema, H.; Mourits, M.; De Bock, G. Ovarian cancer in Lynch syndrome; a systematic review. Eur. J. Cancer 2016, 55, 65-73. [CrossRef] 
104. Berns, K.; Caumanns, J.J.; Hijmans, E.M.; Gennissen, A.M.C.; Severson, T.M.; Evers, B.; Wisman, G.B.A.; Meersma, G.J.; Lieftink, C.; Beijersbergen, R.L.; et al. ARID1A mutation sensitizes most ovarian clear cell carcinomas to BET inhibitors. Oncogene 2018, 37, 4611-4625. [CrossRef]

105. Ji, J.X.; Wang, Y.K.; Cochrane, D.R.; Huntsman, D.G. Clear cell carcinomas of the ovary and kidney: Clarity through genomics. J. Pathol. 2018, 244, 550-564. [CrossRef]

106. Hierro, C.; Matos, I.; Martin-Liberal, J.; De Olza, M.O.; Garralda, E. Agnostic-Histology Approval of New Drugs in Oncology: Are We Already There? Clin. Cancer Res. 2019, 25, 3210-3219. [CrossRef] [PubMed]

107. Herrera, F.G.; Irving, M.; Kandalaft, L.E.; Coukos, G. Rational combinations of immunotherapy with radiotherapy in ovarian can-cer. Lancet Oncol. 2019, 20, e417-e433. [CrossRef]

108. Mazzarella, L.; Duso, B.A.; Trapani, D.; Belli, C.; D'Amico, P.; Ferraro, E.; Viale, G.; Curigliano, G. The evolving landscape of 'next-generation' immune checkpoint inhibitors: A review. Eur. J. Cancer 2019, 117, 14-31. [CrossRef] [PubMed]

109. Bardia, A.; Gounder, M.; Rodon, J.; Janku, F.; Lolkema, M.P.; Stephenson, J.J.; Bedard, P.L.; Schuler, M.; Sessa, C.; Lorusso, P.; et al. Phase Ib Study of Combination Therapy with MEK Inhibitor Binimetinib and Phosphatidylinositol 3-Kinase Inhibitor Buparlisib in Patients with Advanced Solid Tumors with RAS/RAF Alterations. Oncologist 2019, 25, e160-e169. [CrossRef] [PubMed]

110. Bedognetti, D.; Roelands, J.; Decock, J.; Wang, E.; Hendrickx, W. The MAPK hypothesis: Immune-regulatory effects of MAPKpathway genetic dysregulations and implications for breast cancer immunotherapy. Emerg. Top. Life Sci. 2017, 1, 429-445. [CrossRef]

111. Ebert, P.J.; Cheung, J.; Yang, Y.; McNamara, E.; Hong, R.; Moskalenko, M.; Gould, S.E.; Maecker, H.; Irving, B.A.; Kim, J.M.; et al. MAP Kinase Inhibition Promotes T Cell and Anti-tumor Activity in Combination with PD-L1 Checkpoint Blockade. Immunity 2016, 44, 609-621. [CrossRef] 